\title{
The Political Economy of Decentralisation and the Challenge of Improved Service Delivery in Urban Ghana
}

\author{
Abdulai Abdul-Gafaru \\ University of Ghana, Legon \\ agabdulai@ug.edu.gh \\ DOI//http://dx.doi.org/10.4314/gjds.v14i2.5
}

\begin{abstract}
This article explains why several decades of decentralisation reforms have had limited impact on improving access to quality basic services in Ghana, with a particular focus on urban areas. Data was gathered through a review of secondary literature, an analysis of primary documents, and a focus group discussion with the budget and planning officers of three Municipal Assemblies in the Greater Accra region. Devolution reduces the discretionary powers of national political elites, and by extension their capacity to resort to the clientelist distribution of resources as a political survival strategy. Consequently, in countries where politicians at the centre are susceptible to a high degree of vulnerability due to intense electoral competition, topdown elite commitment to decentralisation would most likely remain weak, with significant adverse implications for the capacity of sub-national authorities in delivering their mandates. The article concludes that given the importance of the nature of central-local power dynamics in making decentralisation work for the poor, a fuller understanding of the political constraints to service delivery in urban Ghana would require going beyond an exclusive focus on local power dynamics within cities to an examination of the wider structures of power within which subnational authorities are embedded.
\end{abstract}

Keywords: Political Economy, Decentralisation, Service Delivery, Urban Ghana

\section{Introduction}

As the pace of urbanization accelerates in many developing countries, particularly Africa, scholars have increasingly explored the efficacy of decentralization in enhancing service delivery among growing urban populations (Resnick, 2014; Golooba-Mutebi, 2003). Official policies frame decentralisation as a means to pursue various goals, including improved democratic accountability, service delivery and poverty reduction. Yet, it is now well documented that the decentralization reforms that swept most African countries during the last three decades have achieved very little in terms of enhanced 
downward accountability and improved service delivery (Dickovick \& Riedl, 2014). Eaton, Kaiser, and Smoke (2011) suggest that an important factor that underlies the general disconnect between decentralisation and its expected developmental benefits relates to the limited appreciation of the real reasons for which most governments adopt decentralisation reforms. While decentralisation is often theoretically presented as a means to achieving a wide range of socio-economic development benefits, in reality, decentralization "is intrinsically a political phenomenon that is pursued when it supports the interests of those in power" (Smoke, 2015: 260). Importantly, the specific reasons for which political elites may choose to decentralise power can be significantly different from, and potentially incompatible with, the socio-economic reasons for which decentralisation is often deemed desirable in theory and in policy.

Ghana has had a four-decade long experience of decentralization reforms, and has also experienced one of the fastest growth rates of urbanization in Africa during the last three decades. Between 1984 and 2013, Ghana's urban population more than tripled, rising from under 4 million to nearly 14 million people (World Bank, 2015: 1). However, as cities have grown in both population and area, they have been less successful at providing basic services to local residents. Between 2000 and 2010, there was an increase in the proportion of households without any toilet facility in all city size groups. Solid waste disposal and sewerage also remains a major challenge in most urban centers with significant adverse implications for the health of local residents (World Bank, 2015: 20).

The article addresses two-related questions: why has Ghana's four-decade long experience of decentralisation reforms failed to result in improved service delivery? What are the key political factors that constrain service delivery among the growing urban population in Ghana? Within the context of the rapid rate of urbanisation in Ghana, much of the recent literature that attempt to explore the decentralisationdevelopment disconnect have adopted largely technocratic approaches, emphasising improvements in financing and institutional harmonisation between sectors as the means to improved delivery of municipal services (e.g. World Bank, 2015). Drawing insights from Mushtaq Khan's concept of political settlements (Khan, 2010) which has increasingly gained grounds in explaining the political economy of development in poor countries, this article demonstrates the importance of political economy dynamics for understanding the seemingly-technocratic constraints to service delivery in urban Ghana. The findings suggest that a fuller understanding of the political constraints to service delivery would require going beyond an exclusive focus on local power dynamics within cities (e.g. see Paller, 2014; 2015) to an examination of the wider structures of power within which subnational authorities are embedded.

In what follows, the article first discusses the political economy of service delivery, drawing from the emerging literature on political settlements, before turning to discuss 
the nature of the political settlement in Ghana. After presenting the methodology, the article then shows how the nature of Ghana's political settlement has shaped decentralisation reforms and the ways in which this has shaped the capacity and commitment of city-level governments in the delivery of basic services. The final section concludes and highlights some important lessons.

\section{Political Settlement Theory: Towards an Understanding of the Political Economy of Decentralisation}

The rediscovery of the importance of political economy has been part of a broader movement of rethinking development. In the 1970s, donor agencies and other development practitioners sought to sidestep politics as much as possible and focus advice on technical questions and solutions, both because political incentives appeared so frequently incompatible with development in the public interest and because politics had become so deeply entangled with foreign policy considerations at the time (Fritz, Kaiser and Levy, 2014). In the 1980s, structural adjustment programmes (SAPs) dominated as a policy paradigm for countries seeking broad-based development, including a strong focus on the need to roll back the state through greater decentralized governance. In much of Africa, decentralisation reforms were promoted as part of an underlying neoliberal opposition to the perceived (over)centralized state and the consequent desire to further shrink its powers (Wunsch \& Oluwu, 1990; Campbell, 2001; Crawford \& Abdulai, 2009).

Since the199os, recognition has grown that institutions - the rules of the game - matter, and 'good governance' moved to the centre stage in the development discourse. At this moment, much of the development literature emphasised the importance of 'good' institutions in shaping variations in development outcomes (North, 1990). In more recent years, however, a number of leading proponents have revised their approaches to take greater account of the central role that politics plays in shaping long-run processes of development (North, Walliss and Weingest, 2009; North, Walliss, Webb and Weingest, 2013; Acemoglu \& Robinson, 2012). A central message in this new emerging thinking is the observation that behind institutions lie power and politics: effective institutional (and policy) reform requires coming to grips with the underlying configuration of power that shape the ways in which institutions emerge and are enforced as well as the ways in which institutions change overtime (Fritz et al., 2014).

This line of thinking is most strongly exemplified in Khan's (2010) concept of political settlement, which has increasingly gained ground as means to analysing the political economy of governance reforms. Khan (2010: 1) argues that a "political settlement emerges when the distribution of benefits supported by its institutions is consistent with the distribution of power in society, and the economic and political outcomes of 
these institutions are sustainable over time". Societies cannot develop amid conflict and unrest, and elites in every given society often strive to define acceptable ways in which conflicts over the distribution of power and resources are resolved. A political settlement may be seen as an elite pact wherein the elites of a country negotiate the distribution of power and resources. As Laws and Leftwich (2014: 1) note, political settlement theory is about understanding "the formal and informal processes, agreements, and practices that help consolidate politics, rather than violence, as a means for dealing with disagreements about interests, ideas and the distribution and use of power". In contrast to the 'good governance' agenda that emphasise the adoption of 'best-type' institutions, political settlement theory pushes development thinking beyond an institutionalist approach by focusing on the underlying power arrangements that underpin the emergence, stability and performance of institutions.

Brian Levy has distinguished between two basic types of political settlements (Levy, 2015), depending on how easy it is for opponents to remove the ruling group from power. In dominant political settlements, power is concentrated largely in the hands of a dominant party/leader, and it will take an extraordinary level of effort by regime opponents to wrestle power from the ruling group through the ballot box. The second, contrasting settlement is competitive clientelism which is characterised by a high degree of competition for power and a strong likelihood of power changing hands through the electoral process. Levy (2015: 245) hypothesises that comprehensive decentralisation reforms are more unlikely to gain traction in countries characterised by competitive clientelist political settlements because such "reforms reduce opportunities for discretion in hiring decisions and because ... leaders lack a consistent and log-term orientation toward change". In such settings, because of the highly vulnerable nature of those in power due to intense electoral competition, ruling elites tend to be more committed to policy reforms that contribute to their short-term political survival (Booth \& Cammack, 2013). Decentralising substantial authority and discretionary powers to sub-national governments is unlikely to help promote the short-term political calculus for national elites. In competitive clientelist political settlements, therefore, elite commitment to genuine decentralisation reforms are likely to remain weak.

The political settlements perspective has advantages over previous attempts at offering political explanations to the generally limited impact of decentralisation on development outcomes in the global south. In much of the current literature on decentralization, the role of politics is often imprecisely framed in terms of the need for greater "political will" on the part of central government officials (Smoke, 2015). As Crawford (2009) has argued, such calls for improved top-down elite commitment as the means to making decentralisation work for the poor are both problematic and naive, given that "governments rarely give up their power voluntarily". Motivations 
for decentralisation often include extending and strengthening national elites' control at the local level through the mobilization of support for the ruling party in peripheral areas. The political settlements perspective helps us avoid unrealistic assumptions about national elites' commitment to relinquishing power through decentralisation. Instead, it draws our attention to the fundamental fact that "the nature of social relations and the associated distribution of power" (Smoke, 2015: 253) in any given polity is an important factor for understanding the extent to which national elites are likely to be committed to devolving power to subnational authorities. In this respect, political settlements approach moves us beyond conventional recipes, by helping us to identify some specific conditions under which national political elites are likely to be committed to genuine decentralisation reforms.

The political settlement in Ghana is characterised by 'competitive clientelism' where intense electoral competition renders ruling political elites very vulnerable (Abdulai, 2017; Abdulai and Hickey, 2016; Hirvi \& Whitfield, 2015). Ghana transitioned from decades of political instability in the immediate post-independence era to a decade of a stable quasi-military experiment (1982-1992) and then to a stable multi-party democratic rule from 1993 to date. Although several parties have contested all seven sets of elections held since 1992, Ghana remains a de facto two-party state in which the New Patriotic Party (NPP) and the National Democratic Congress (NDC) have increasingly become equal in their capacity in mobilizing voters. Consequently, of the last four set of presidential elections held between 2000 and 2016, three resulted in an alternation of power between the NDC and NPP.

Importantly, because of the winner-takes-all character of Ghanaian politics, each ruling coalition is characterised by a high degree of vulnerability in power, leading to the politicisation of public institutions. In this context, patronage-based appointments in Ghana has become a norm; every transition of power is accompanied by the removal of a significant number of senior public servants perceived to be associated with the previous regime (Gyimah-Boadi \& Yakah, 2012). Extreme partisanship in public appointments has been an enduring feature of competitive clientelism in Ghana, as members of the two dominant parties see the control of the state as the most lucrative avenue for group and individual wealth and influence. How have these political dynamics shaped decentralisation reforms in Ghana, and what have been the implications for effective service delivery at the local level?

\section{Decentralisation in Ghana: A brief Historical Account}

The history of decentralisation in Ghana is often traced as far back as the colonial period, beginning with the introduction of indirect rule by British colonial authorities in 1878. During this period, the colonial administration ruled the Gold Coast through 
Native Authorities (i.e. the chieftaincy institution), by constituting the chief and elders in a given district as the local authority (Nkrumah, 2000). It was not until the 1950s that elected town and municipal councils were set up. In the post-independence period from 1957 onwards, local government was generally weak and subject to the centralisation of power that was typical of the post-colonial state in Africa as a whole (Crawford, 2004). Attempts at decentralisation reforms were introduced at different times, with differing implications for effective citizen engagements. In general, decentralisation reforms during this period was characterised by deconcentration, aimed primarily at strengthening central government control at the local level (Nkrumah, 2000).

It was not until the early 1980 os that two major factors led to change: i) the assumption of office by the Jerry Rawlings-led the Provisional National Defence Council (PNDC) quasi-military regime with its political slogan of 'power to the people'; and ii) the World Bank-inspired structural adjustment policies, which forced governments to develop decentralisation policy reforms as a way of reducing the size and responsibilities of central governments (Mohan, 1996).

The current system of decentralization was introduced in 1988. After seizing power in 1981, the Rawlings-led PNDC regime announced that "power will not be concentrated at the top anymore" (Yeebo, 1985). The first reform the regime undertook was an administrative decentralisation seeking to increase government efficiency in the face of dwindling state resources. This reform, first announced in 1983, entailed the deconcentration of central government ministries alongside the creation of Peoples Defence Committees (PDCs) in each town and village. The PDCs, made of local PNDC activists as self-identified defenders of the 'revolution', effectively took over local government responsibilities, though often limited to mobilising the implementation of local self-help projects while the deconcentrated ministries played a more significant role (Nkrumah, 200o). Political decentralisation did not take place until 1988 when a new Local Government Law (PNDC Law 207) was passed. This law established a new local government system in which newly created District Assemblies (initially 110) were to be designated as the highest political and administrative authority responsible for developmental decision-making at the local level.

Democratic local elections were introduced under the 1988 reforms, though with two important caveats worth highlighting. First, local government elections were to be conducted on a non-partisan basis in which candidates would contest as individuals rather than on the basis of party tickets. This approach was in line with the wider political context at the time, in which political party activity was banned altogether. Second, although the introduction of local elections represented a significant advance of the 1974 local government reforms where all District Council members were appointed 
officials, the PNDC's reforms still fell far short of a fully-devolved local government system in at least two ways:

i) Under the reforms, only two-thirds of DA members were to be elected, while the remaining third were to be chosen by the government from among civil society members;

ii) Instead of allowing the elected DA members to elect one of their own as the Mayor, or better still, allow the direct election of Mayors by local populations, the regime continued on the path where District Chief Executives (DCEs) or Mayors were appointed. Moreover, all the politically loyal cadres appointed to head the DAs could only be removed by Jerry Rawlings, and not the elected Assembly members or the people.

Three years after the PNDC regime started its version of political decentralisation reform, it was compelled to return the country to multiparty democracy by a combination of pressures from the international donor community and some domestic actors such as banned political groups; as well as the regime's own need for greater legitimacy. However, the administration managed to exclude local government from the multiparty process because donors and political groups were more concerned with national politics and less about local governments. As a result, a partisan political system at the national level was superimposed on a non-partisan local government system (Awortwi, 2010), which remains the current situation.

The 1992 Constitution of Ghana, which marked the transition to multi-party democracy, endorsed the principles of decentralisation with detailed participatory structures and processes outlined in the Local Government Act of 1993, Act 462. The DA system was incorporated into the new Constitution, with further efforts aimed at strengthening their financial viability through the establishment of a District Assemblies Common Fund (DACF).

\section{Methodology}

Conducted as part of a larger study of which this author was part ${ }^{3}$, evidence for this article is drawn from three main sources. The first was an extensive review of secondary literature, focusing particularly on peer-reviewed studies and data from government sources. The aim of this review was to identify core issues and debates around the political drivers of Ghana's decentralization reforms and their implications for the effective functioning of municipal and metropolitan authorities. The second was an

3 This paper is part of a wider project commissioned by Cities Alliance on the theme: Urban Governance and Services in Ghana. 
analysis of primary documents ${ }^{4}$ and data from the 2010 population and housing census and the District Assembly Common Fund. These two data sets were used to compute DACF per capita allocations for the six largest urban-based metropolitan Assemblies in order to interrogate claims regarding the urban-biased orientation of the disbursement criteria of the DACF (e.g. see Botchie, 2000; Tsekpo \& Jebuni, 2008). Third, the article benefited from the author's participation in a two-day workshop organized jointly by Cities Alliance and the Accra-based Institute of Local Government Studies on April 1314, 2016. This workshop brought together 41 stakeholders from municipal assemblies, ministries and agencies and civil society to discuss urban governance challenges in Ghana. Towards the end of the end of the workshop, the author conducted a focus group discussion with the municipal budget and planning officers of the Tema Metropolitan Assembly (TMA), the Adentan Municipal Assembly (AMA), and the Ga East Municipal Assembly (GEMA) - all in the Greater Accra region. These discussions served as additional sources of information for the article especially with regards to how political forces shape the operations of urban government authorities.

\section{The Political Economy of Decentralisation in Ghana: Implications for Urban Service Delivery}

This section shows how partisan political considerations within Ghana's competitive clientelist setting have effectively undermined both the democratic nature of decentralized governance and the potential of decentralization to contribute to improved service delivery in urban areas. The discussion focuses specifically on central government control of subnational authorities through presidential appointments and budgetary controls.

\section{Central Government Appointments}

One of the key features of Ghana's local governance system is the persistence of central government appointees in highly influential positions at the local level. While democratic decentralization requires the transfer of power and resources to elected subnational authorities, there remains a lingering direct central government influence on the composition of Ghana's local authorities which are characterised as Metropolitan, Municipal, and District Assemblies (MMDA). ${ }^{5}$ The main means by which direct central government control is exerted at the local level is the appointment of $30 \%$ of all MMDA

4 Among the primary documents used for this study are Ghana's 1992 Constitution, the report of the Constitutional Review Committee (2011), and the government of Ghana's White Paper on the Constitutional Review Committee report (2012).

5 How exactly a given Assembly is characterized depends on the level of population and service provision. 
members by the president, and of the Metropolitan, Municipal and District Chief Executives (MMDCEs) who are the highest political authorities at the local level. While this appointment system has been officially justified on grounds that it would help bring advantages of knowledge, professional and technical expertise to bear on the work of local authorities, as well as ensure the representation of marginalized groups like women (Ayee \& Dickovick, 2010), in practice, this system has been the means of providing the party in power with the opportunity to appoint party loyalists at the expense of opposition party supporters. Thus, rather than strengthening meritocratic appointments of local government authorities, the current system has contributed to providing the president a means by which to patronise local elite groups. Consequently, MMDCEs are typically appointed from amongst the key office-holders in the local branch of the governing party, and have accordingly tended to serve as conduits through which governing elites exert control on local politics and development (Crawford, 2010). Key local government officials such as MMDCEs have therefore become little more than extensions of the executive branch at the local level, and as such, remain largely unaccountable to local populations.

In the focus group discussion held with the planning and budget officers of the Tema, Adentan and Ga East Municipal Assemblies in the Greater Accra region, participants highlighted several adverse implications of the upwardly unaccountable nature of MMDA officials for effective service delivery, including the award of dubious contracts to party cronies that lead to the shoddy execution of projects. In one instance, participants cited the example of one DCE constructing a 40-seater toilet block without the provision of water that is necessary for the functionality of the toilet facility. This observation echoes Booth and Therkildsen's (2010: 18) point about the "tendency of competitive clientelism, especially in its democratic form, to generate policy incoherence" - a situation in which bold policy gestures that are often announced to help win elections are are rarely accompanied by the necessary complementary measures that will lead to desired impact. Moreover, due to pressures exerted by some MMDCEs, local development planners are sometimes compelled to set aside development plans and reallocate resources in ways that are deemed more politically suitable in enhancing the electoral fortunes of the parties that appointed them.

Together, these problems explain why public opinion in Ghana has long been heavily steered towards the full democratization of the MMDAs, with $100 \%$ elected members and locally elected MMDCEs (African Peer Review Mechanism, 2005; Constitution Review Commission, 2011). Although the two dominant political parties have, at different times, indicated their commitments to a fully devolved local government system, none in power has initiated the necessary reforms aimed at changing the status quo. Instead, both parties advocate he election of MMDCEs only when in opposition, 
but often backtrack from such commitments when they are in power. During the 2000 presidential elections, the NPP pledged to amend the constitution to allow the election of all MMDCEs, but soon abandoned this idea after assuming office in January 2001. Indeed, once in power, the NPP fully used its appointment power by revoking the mandates of all MMDCEs put in place by the previous NDC regime and appointed those allied to the new ruling party (Crawford, 2009). Interestingly, once the ruling NPP abandoned its calls for greater decentralization, the NDC, then in opposition, embraced it and pledged

to reform and deepen democratic decentralisation in its 2008 election manifesto (NDC, 2008: 14).

However, and as with the NPP in 2001, the NDC which won the 2008 and 2012 elections and remained in power till December 2016, faced incentives to perpetuate the status quo in which the central government has considerable appointment power over officials at subnational levels. In 2010, the NDC Government established a Constitutional Review Committee (CRC) to conduct a public consultative process towards a review of the 1992 Constitution. Although the CRC recommended the election of all MMDCEs (CRC, 2011), a government White Paper issued afterwards categorically rejected this recommendation, claiming that "in decentralizing in a unitary state, a delicate balance ought to be struck between central control and local autonomy" (Republic of Ghana, 2012: 34). This raises the important question of why political parties often favour greater political devolution only when in opposition. One key answer relates to the partisan political advantages associated with the appointment system for ruling parties, particularly as it relates to the multiple opportunities for district level patronage that comes with the current system. While the election of MMDCEs can provide parties in opposition an opportunity to maintain some sub-national level support even as they are out of power nationally, the party holding the presidency has little incentive to alter arrangements that favour central appointment power (Ayee \& Dickovick, 2010). Thus, while the current NPP administration has promised to allow citizens to elect all Assembly members and MMDCEs from 2018 onwards, it remains to be seen if this would really happen in practice.

\section{The Politics of Citizen Participation in Local Governance Processes}

The 1992 Constitution of Ghana speaks of decentralisation as the means to "making democracy a reality" and goes on to affirm the importance of the principles of citizen participation and downward accountability of local officials to the populace (Republic of Ghana, 1992). Accordingly, several formal sub-district structures (e.g. Town and Zonal Councils, and Unit Committees) have been established to serve as mechanisms for promoting citizens' participation in the management of local affairs. In reality, however, these structures have largely failed to perform their functions effectively. Three major factors account for the weakness of the sub-district structures: First, many of them lack the requisite human and material resources to perform their functions effectively. 
Second, there is general apathy towards the operations of these structures because most people who are working on them are not paid; being a member of these structures is completely sacrificial and voluntary. Third, because of their non-lucrative manner, some of the sub-district structures cannot operate because they lack the required number of memberships (Ayee \& Amponsah, 2003: 70).

Rather than focus on resourcing these dysfunctional local government substructures as a way of stimulating popular participation in local and urban governance, various government have demonstrated greater commitment toward the creation of more sub-national administrative units. The last decade in particular has witnessed a steady increase in the number of MMDAs, which more than doubled from 110 in 1988 to 216 by 2012. Importantly, whilst the Local Government Act spells out three important criteria for the creation of new districts, ${ }^{6}$ the available evidence suggests that many of the recently created local government areas did not meet these criteria. Indeed, of the 216 MMDAs in 2010, as many as 31 did not meet the most basic criteria of population threshold (Owusu, 2015), suggesting political considerations in their creation. Not surprisingly, almost $40 \%$ of MMDAs with populations lower than the legally-required minimum threshold are presently located within the two main electoral 'vote banks' of the two dominant parties, namely the Ashanti and Volta regions for the NPP and NDC respectively (Ibid). Ayee (2013: 16) describes the continuous fragmentation of MMDAs as 'a patronage-building exercise' that serves as a means of rewarding loyal ruling political party members through appointments as MMDCEs and enhancing the electoral fortunes of ruling parties through gerrymandering (see also Owusu, 2015; Mohammed, 2015). Unsurprisingly, the three most recent waves of district creation occurred either during election years (2004 and 2012) or just a year prior to elections (2007).

Importantly, these political imperatives have had adverse implications for the effective delivery of basic social services in urban areas. Not only does the increased fragmentation require that available limited resources be spread thinly across a larger number of Assemblies, it has also made it difficult for Assemblies to realise economies of scale and the efficient use of physical, financial and human resources and common infrastructure across a wider contiguous area. Additionally, the continuous fragmentation of districts and town councils has created a situation where larger metropolitan areas are governed across a large number of jurisdictions in a context where there are no clear institutional framework for coordination and collaboration among MMDAs and between MMDAs and key utility providers. This results in

6 Act 462 spells out three main criteria for the creation of new local government areas in Ghana, namely: minimum population threshold; geographical congruity and; economic viability.

7 The NPP government created 28 and 32 new districts in 2004 and 2007 respectively, while the current ruling NDC created 42 new districts in 2012 elections. 
coordination failures both within and across key agencies, undermining the effective and efficient delivery of basic services (see also ICF Consulting, 2017).

\section{Voter Apathy in MMDA Elections}

Although elections provide an important formal mechanism for holding local and urban governments to account, voter apathy in MMDA elections in Ghana has remained consistently high since the return to multiparty democracy in 1992. Turnout for the most recent 2015 MMDA elections was an abysmal 39\%, compared to $79.4 \%$ and $68.6 \%$ in the 2012 and 2016 presidential elections respectively. This problem is an apparent manifestation of the low confidence of citizens about their control of, and benefits from, local level decision making processes that remain dominated by political appointees.

The most important factor that explains these variations is the different contexts within which national and local level elections are conducted in Ghana. On the one hand, presidential and parliamentary elections are fought on a partisan competitive basis, incentivising political parties to encourage and mobilize their supporters to vote. On the other hand, partisan politics is forbidden in local government elections, and individuals seeking elections into the MMDAs are required to stand as 'non-partisan' candidates. Political parties are also formally prohibited from endorsing and sponsoring persons seeking election into an Assembly or its sub-district structures. Ahwoi (2010: 43) argues that the idea of non-partisanship is informed by historical experiences during the early postcolonial period when political parties "hijacked" local governments and "imposed" candidates on the people, and that "by making local elections non-partisan, the electorate are enabled to make choices based on the acceptability, conduct and performance of candidates and not the political parties that they represent".

Yet, the real reasons behind the so-called non-partisan local governance system today has nothing to do with the fear of parties "imposing" candidates on the electorates, but is instead driven primarily by the in-built advantage and control that this system provides for governing parties. In particular, the two dominant political parties have been committed to maintaining the status quo for the fear that partisan MMDA elections can cause them to lose control over certain parts of the country, especially in the electoral strongholds of their opponents.

Non-partisan politics at the local level is also believed to have the potential of preventing opposition party officials from sabotaging the implementation of central government policies at the local level. In this respect, ruling politicians are able to avoid the problem of vertically-divided authority - a situation where central governments sabotage opposition-controlled municipal areas in terms of the distribution of public resources. Resnick (2014) has shown how this phenomenon has contributed to undermining 
the delivery of urban services in Senegal, South Africa and Uganda. Political parties have also resisted the election of MMDCEs on partisan political basis because they have successfully devised strategies of circumventing the legal requirements of nonpartisanship, while at the same time avoiding the political implications of an explicitly partisan electoral system. Whereas the current system of non-partisan elections (at least formally) enables ruling elites to avoid the likely occurrence of the problem of 'verticallydivided authority', in reality, the so-called non-partisan nature of MMDA elections has been a myth; the two dominant political parties both "discreetly, or in some cases, support candidates openly" (Ghana News Agency, 2015).

One of the most recent manifestations of political party interference in district level elections relates to the election of Presiding Members (PMs), who, in theory, are to be elected from among the non-partisan assembly membership. However, recent developments show that PMs are often elected along partisan lines, mainly because Metropolitan and Municipal Chief Executives require the support of PMs who share the partisan political ideologies of the governing party in order to garner the requisite support for their administrations (Adamtey, 2014). This situation has often resulted in deadlocks in the election of PMs in MMDAs where there is an equal level of support for the two main parties among Assembly members, and where these members take entrenched positions to vote for PMs deemed to be sympathetic to their parties. Precisely for this reason, several Assemblies have often lacked PMs for years, with significant adverse implications for local economic development and service delivery.

Recent examples of this come from the Kumasi Metropolitan Assembly ${ }^{8}$ and the Asante Akyem North Municipal Assembly which failed to elect a Presiding Member after conducting 16 elections in seven sittings. Consequently, the Assembly did not have a PM for nearly three years. This was at a time that the Assembly needed a PM before it could confirm the President's nominee for the position of Municipal Chief Executive (MCE). The failure to elect a PM and subsequently confirm the President's nominee for the position of Municipal Chief Executive meant that many development projects and other foreign donor funding such as the District Development Facility (DDF) eluded it. ${ }^{9}$

8 For details, see Lauretta Timah (2016), 'KMA fails to elect Presiding Member after 8th try'. Available at: http://citifmonline.com/2016/og/27/kma-fails-to-elect-presiding-member-after-8th-try/; Daily Graphic (October 13, 2016), 'KMA elects Amakomhene as new Presiding Member'. Available at http://www.graphic. com.gh/news/general-news/kma-elects-amakomhene-as-new-presiding-member.html;

9 For details, see Daily Graphic (July o6, 2013), 'Asante-Akyem Central Municipal Assembly gets MCE and PM'. Availale at: http://www.graphic.com.gh/news/politics/asante-akyem-central-municipal-assembly-gets-mceand-pm.html 


\section{Politics and Intergovernmental Transfers}

Intergovernmental fiscal transfers (IGTs) provide the bulk of revenue for sub-national financing of development in most developing countries. In Ghana, the most significant IGT is the District Assembly Common Fund (DACF), which provides a constitutionally guaranteed minimum share of central government's grants to metropolitan and municipal authorities. Created by the 1992 Constitution, the DACF is a formulaic-based approach to making financial transfers from the central government to all MMDAs in Ghana, and presently comprises $7.5 \%$ of total government revenues. Although the DACF alone accounts for an average of 80\% of MMDA revenues (World Bank, 2015: 39), its management framework is characterized by three key features that undermine its capacity as an effective financing mechanism for urban local governments: (1) allocation formulas that result in limited per capita financing for municipal and metropolitan areas; (2) political clientelism that manifests itself in central government's deductions for funding priority political projects; and (3) the manipulation of allocation formulas by politicians in line with the electoral incentives of ruling parties.

\section{A Rural-biased Distribution Formula}

Although some scholars have sought to characterise the DACF as an urban-biased intergovernmental transfer mechanism (Botchie, 2000; Tsekpo \& Jebuni, 2008) ${ }^{10}$, the findings in this paper suggest that the formula for DACF allocation have often resulted in much lower per capita allocations to urban-based Assemblies. Based on data obtained from the Office of the District Assemblies Common Fund and the 2010 population census, Figure 1 shows that average DACF per capita allocations for the largest urbanbased Assemblies have in most cases been much lower than the national average. This observation is consistent with evidence in a recent World Bank (2015) study which showed that whereas Ghana's six metropolitan Assemblies account for about 22 per cent of the country's population, they receive, on average, only about 11 per cent of DACF transfers. In 2012, the share of the Greater Accra Metropolitan Assembly was only 1.7\% of the DACF, although this large metropolis hosts almost $8 \%$ of Ghana's population (Ibid). Overall, therefore, "metropolitan assemblies receive less than half of the transfer received by district assemblies in rural areas" (World Bank, 2015: 40).

10 These studies are problematic because their conclusions were based on absolute allocation figures rather than on per capita analyses. 


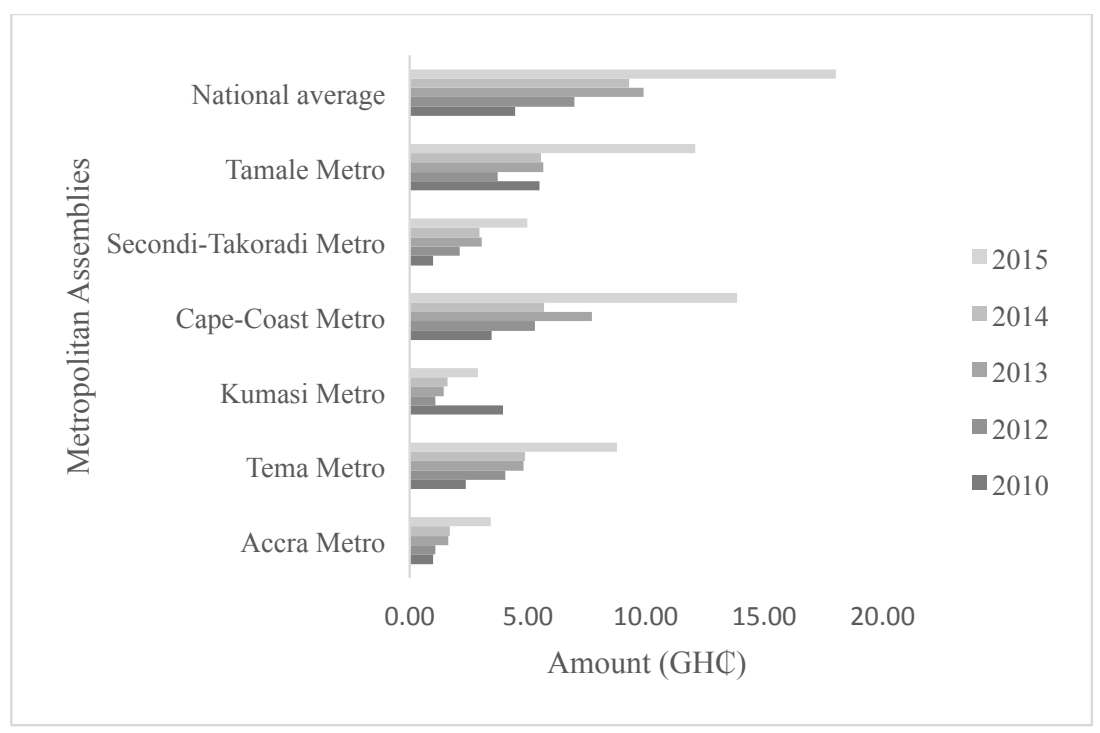

Fig. 1: DACF per capita for Metropolitan Assemblies, 2010-2015

Source: Author, based on 2010 population census and data from DACF Secretariat, Accra

These outcomes arise mainly from the weights assigned to various factors in the DACF allocation formula. Since 1994, four main factors have been considered in calculating the various MMDAs' shares of the DACF: equity/need, equality, responsiveness and service pressure. Two important observations are worth noting here. First, of these factors, the only one that disproportionately favours urban-based Assemblies is the 'service pressure' factor - an allocation based on population density as an indicator of pressure on financial needs. While this factor is expected to compensate urban areas for the pressures put on their facilities as a result of rural-urban migration (Republic of Ghana, 2014: 13), it has historically received too small a weighting in computing DACF allocations. Since 2012, the 'service pressure' factor has consistently received the least weight of around 2\%, down from 10\% in 2010 and 6\% in 2011. Second, between 2004 and 2011, the weight assigned to the 'equality' factor in computing the districts' allocated sums consistently remained between $50 \%$ and $60 \%$, but has since then reduced slightly to the range of between 40 to $50 \%$. This means that either about half or more of the entire DACF envelop has often been shared equally among MMDAs regardless of their population size. Together with the fact that the number of MMDAs has risen sharply over the last few years, the consistently higher weights assigned to the equality and equity factors in the formula have combined to skew DACF allocations against the large and medium sized cities which have a relatively higher service delivery and infrastructure investment requirements. This skewed allocation formula distorts the 
capital supply to urban local authorities under DACF and severely restricts their ability to invest into capital projects for long term service delivery.

\section{Clintelist Politics and Central Government's Control over Municipal Budgets}

Clientelist politics further undermines the impact of the DACF on service delivery through the use of 'earmarks' to fund central government's priority political projects. Over the years, the DACF has suffered various statutory deductions from the centre, undermining the capacity of sub-national authorities in implementing local development initiatives. During election campaigns, the two main political parties compete forcefully for votes through promises to the electorates to provide the quality services which the MMDAs are perceived to have failed to provide. After winning elections, the central government then earmarks funds from the DACF to carry out its manifesto promises at the subnational level.

Through the Ministries of Finance and Local Government, the central government also issues annual directives and/or guidelines as to how MMDAs should utilize their DACF releases. Together, these practices have effectively turned subnational government institutions into deconcentrated agencies, rather than fiscally autonomous authorities capable of implementing their own locally-designed medium-term development plans. In some years, as in 2012, central government directives to the MMDAs determine about 75 per cent of DACF expenditure via "earmarks". These unilateral deductions and/or earmarks are supposedly used for a variety of purposes, particularly for centralized bulk procurement of equipment, as well as for services to be supplied to assemblies in areas such as sanitation and waste collection. As the MMDAs are themselves not party to the contractual processes, such centralized procurement practices are often characterized by lack of transparency and accountability. During focus group discussions, some Assembly officials pointed out that they have had major difficulties in attempting to verify the cost of capital equipment that has been bulk purchased on their behalf and for which payments have been centrally deducted from the assembly account.

These constraints are the direct outcome of the underlying political economy in Ghana. The early push for contracting out of waste operations has been an outcome of post structural adjustment policy of government with strong pressure from the donor community to seek alternative service delivery models in public service delivery. This stems from an implicit assumption that the private sector will be better placed to operate services at lower cost and with greater efficiency. However, in an imperfect market, where the institutional structures and arrangements governing management contracts are still somewhat immature, and where wider political and economic interests are accommodated through a variety of informal and semi-formal mechanisms and channels, public service outcomes are variable and problematic. This is illustrated 
by the fact that certain contracts have been established, expanded and rolled out country wide by the central government without competition, creating a monopoly like situation over certain aspects of waste management which are in turn bolstered by a variety of informal arrangements and subtle pressures that have maintained the status quo over two 'rival' political incumbencies. This is the case with Government's contract with Zoomlion Ghana Ltd., for example, which is administered through a set of non-transparent deductions from one tier of government to another. Another feature of the political economy of waste management relates to the fact that contracting out is perceived to be a way in which the central government can out-source its functions without assuming any shared financial responsibility, while continuing to maintain full political control over the charges and fees to operators.

In this context, a sub-national financing framework that focuses on increasing local revenue generation and reducing MMDAs' dependence on central government transfers could help mitigate these financing challenges. However, here too, central level political constraints are evident. In particular, based on the Local Government Act of 1993, MMDAs are only permitted to borrow $\mathrm{GH} \bigotimes 2000$ (\$50); for any borrowing beyond this amount, the MMDAs need the permission of central government, which has deterred them from borrowing till date. In 2008, a draft bill was prepared to review the borrowing threshold and presented to parliament on two occasions but could not be passed into law. In effect, while limited financing certainly remains a major constraint, this problem needs to be understood not simply as a technical capacity issue but also as political in nature, underpinned by central government requirements that both undercuts the discretionary powers of local governments to plan and utilize allocated financial resources from the centre, as well as reduces the borrowing capacities of sub-national authorities.

\section{Conclusions and implications}

The World Bank (2015: 36-37 \& 47) has recently argued that most of the problems facing urban local governments in Ghana "are caused by inadequate financial resources" and that improving the efficiency of the country's urban system and of urban service delivery will depend on "the provision of adequate financing". While the study acknowledged the ineffectiveness of local government reforms in addressing the challenge of effective service delivery in urban Ghana, it concludes that this has primarily been "because of prevailing contradictions in the legal framework and the insufficient transfer of human resources and capital to MMDAs."

This paper has shown that political economy factors are as important for understanding the constraints to effective decentralized governance and service 
delivery in urban Ghana as funding and technical capacity. Indeed, even seemingly technical capacity challenges associated with inadequate financing have important political underpinnings, particularly in terms of central government requirements that undercut the discretionary powers of local governments to plan and utilize allocated financial resources from the centre. The evidence presented here shows that an understanding of political impediments - whether they emerge from partisan incentives to retain appointment powers over sub-national officials, ministerial objectives to set expenditure rules for sub-national governments, the use of 'earmarks' in IGTs for funding central government's priority political projects, or the continuous fragmentation of metropolitan assemblies - are crucial to understanding why decentralization has failed to lead to improved delivery of urban services in Ghana.

The decentralization legacy in Ghana derives from its colonial and post-colonial past, where non-democratic governments at the centre established local government as a lower tier agency that could reinforce central legitimacy through localized patronage networks. Over time, this has created a class of 'collaborative politicians' that function as a conduit between local level constituencies and centralized power. Since the return to multiparty democracy in 1992, this problem has been further reinforced by the competitive nature of clientelist politics in Ghana, in which two political parties compete in the use of elections as a mechanism for the distribution of patronage and state resources to award followers. In this political environment, local governments are actively controlled by the central government both in terms of appointment and distribution of resources.

Competitive clientelism and the associated power struggles that take place have had negative consequences for decentralized governance and service delivery in various ways. Local assembly representatives are formally apolitical, but have close ties to political parties - and party priorities often direct resources into patronage spending rather than investing in the provision of public goods. Rather than professional competency, party political affiliation is the main basis of appointing local Assembly officials. In this respect, whatever development policy that gets approved is what the ruling party supports and not necessarily what the majority of the people want. Therefore, in order to understand why the over three-decade old decentralization reforms in Ghana have not been able to effectively address the problem of poor service delivery, it is important to analyze the problem of political interference and informal practices and the effects of the informal institutional context, particularly the country-specific political settlements within which subnational governments operate. Overall, then, the political settlements approach moves us beyond the usual calls for greater 'political will' as the means to making decentralisation work for the poor, to an identification of some specific country contexts that are likely to enhance or hinder 
genuine political commitment to decentralisation. Finally, the findings here suggest that given the constraints imposed on subnational authorities from the centre, governance reforms that focus exclusively on the micro-environment (or within-city political dynamics) will have little chance of success in terms of improved service delivery for urban populations. Instead, successful reforms will require a consideration of two inter-related dynamics relevant to governance contexts at both local and national levels (Resnick, 2014).

Acknowledgement: This paper derives from a Cities Alliance and DFID Research Monograph on Urban Governance and Services in Ghana, Richard Slater (ed) 2016 funded under the Cities Alliance Future Cities Africa Research Project.

\section{References}

Abdulai, A-G. (2017).The political economy of regional inequality in Ghana: Do political settlements Matter? The European Journal of Development Research, 29(1), pp. 213229.

Abdulai, A-G. and Hickey, S. (2016). The Politics of development under competitive clientelism: Insights from Ghana's Education Sector. African Affairs 115(458), pp. 44-72.

Abdulai, A-G and Hulme, D. (2015). The politics of regional inequality in Ghana: State elites, donors and PRSPs. Development Policy Review 33(5), pp. 529-553.

Acemoglu, D. and Robinson, J. (2012). Why nations fail: The origins of power, prosperity and poverty. New York: Crown Business.

Adamtey, R. (2014). Deepening decentralisation through non-partisan district assembly system in Ghana. Journal of Science and Technology, 34(No. 1), pp. 75-84.

African Peer Review Mechanism. (2005). Country review report and programme of action for the Republic of Ghana. APRM Secretariat: Midrand, South Africa.

Ahwoi, K. (2010). Local government and decentralisation in Ghana. Accra: Unimax Macmilland Ltd.

Awortwi, N. (2010). The past, present, and future of decentralization in Africa: A comparative case study of local development trajectories of Ghana and Uganda. International Journal of Public Administration 33: pp. 620-634.

Ayee, J. R. A. (2013). The political economy of the creation of districts in Ghana. Journal of Asian and African Studies 48(5), pp. 623-645.

Ayee, J. R. A., and Amponsah, N. (2003). The district assemblies and local governance: Reflections on the 2002 local elections. In Local government in Ghana: grassroots participation in the 2002 local government elections, J. R. A. Ayee, N. Amponsah (Eds.). Accra: Livog Limited. 
Ayee, J. and Dickovick, J. T. (2010). Comparative assessment of decentralization in Africa: Ghana desk study. Washington DC: United States Agency for International Development.

Booth, D. and Cammack, D. (2013). Governance for development in Africa: Solving collective action problems. London: Zed Books.

Booth, D. and Therkildsen, 0. (2012). The political economy of development in Africa: A joint statement from five research programmes, Africa Power and Politics Programme, Developmental Leadership Programme, Elites, Production and Poverty: A Comparative Analysis, Political Economy of Agricultural Policy in Africa. Tracking Development.

Botchie, G. (2000). Rural district planning in Ghana: A case study. Environmental planning issues No. 21. London: International Institute for Environment and Development.

Campbell, B. (2001). Governance, institutional reform and the state: International financial institutions and political transition in Africa. Review of African Political Economy, pp. 88: 155-76.

Constitution Review Commission. (2011). From a political to a developmental constitution. Report presented to the President of the Republic of Ghana, December 20, 2011.

Crawford, G. (2004). Democratic decentralisation in Ghana: Issues and prospects. POLIS working paper No. 9. University of Leeds, UK: School of Politics and International Studies.

Crawford, G. (2009). Making democracy a reality? The Politics of decentralization and the limits to local democracy in Ghana. Journal of Contemporary African Studies 27(1), pp. 57-83.

Crawford, G. (2010). Decentralisation and struggles for basic rights in Ghana: opportunities and constraints. International Journal of Human Rights 14(1), pp. 92125 .

Crawford, G. and Abdulai, A-G. (2009). The World Bank and Ghana's Poverty Reduction Strategies: Strengthening the state or consolidating neo-liberalism? Labour, Capital and Society 42(182), pp. 82-115.

Dickovick, T. and Riedl, R. B. (2014). African decentralization in comparative perspective. In Decentralization in Africa: The paradox of state strength, by D. Tyler, and W. James, Eds., Boulder, Colo: Lynne Rienner; pp. $249-76$.

Eaton, K., Kaiser, K. and Smoke, P. (2011). The political economy of decentralization reforms. Washington DC: The World Bank.

Elections - $C O D E O$. Available at: www.ghananewsagency.org/print/93439 Accessed 19th July, 2016. 
Fritz V, Kaiser K, Levy B. (2009). Problem-driven governance and political economy analysis: Good practice framework. World Bank: Washington DC.

Ghana News Agency. (2015). Political party interference marks upcoming assemblies'

Golooba-Mutebi, G. (2003). Devolution and outsourcing of municipal services in Kampala City, Uganda: An aarly assessment. Public Administration and Development 23: pp. 405-418.

Gyimah-Boadi, E. and Yakah, T. (2012). Ghana: the limits of external democracy assistance, UNU-WIDER working paper No. 2012/40 (Helsinki: United Nations World Institute for Development Economics Research)

Hirvi, M., and Whitfield, L. (2015). Public-service provision in clientelist political settlements: Lessons from Ghana's urban water sector. Development Policy Review, 33(2), pp. 135-158.

ICF Consulting Services (2017). Urban governance and services in Ghana institutional, financial and functional constraints to effective service delivery. Study commissioned by Cities Alliance, Brussels.

Khan, M. (2010). Political settlements and the governance of growth-enhancing institutions. Working Paper (unpublished). University of London: London School of Oriental and African Studies.

Laws, E., and Leftwich, A. (2014). Political settlements, concept brief 1. Birmingham: Developmental Leadership Programme. LP.

Levy, B. (2015). Governance reform: Getting the fit right. Public Administration and Development, 35, pp. 238-249.

Mohammed, A. K. (2015). The politics of municipal fragmentation in Ghana. Commonwealth Journal of Local Governance Issue 16/17, pp. 168-189.

Mohan, G. (1996). Adjustment and decentralization in Ghana: A case of diminished sovereignty. Political Geography, 15(1), pp. 75-94.

NDC. (2008). Manifesto for a better Ghana 2008. National Democratic Congress: Accra.

Nkrumah, S. (2000). Decentralisation for good governance and development: The Ghanaian experience. Regional Development Dialogue, 21(1), pp. 53-67.

North, D. C. (1990). Institutions, institutional change and economic performance. Cambridge: Cambridge University Press.

North, D. C., Walliss, J. J. and Weingest, B. R. (2009). Violence and social orders: A conceptual framework for interpreting recorded human history. Cambridge: Cambridge University Press. . 
North, D. C., Walliss, J. J., Webb, S. B., and Weingest, B. R. (2013). In the shadow of violence: Politics, economics, and the problems of development. Cambridge: Cambridge University Press. .

Owusu, G. (2015). Decentralized development planning and fragmentation of metropolitan regions: The case of the Greater Accra Metropolitan Area, Ghana. Ghana Journal of Geography 7(1), pp. 1-24.

Paller, J. (2014). Informal institutions and personal rule in urban Ghana. African Studies Review 57(3), pp. 123-142.

Paller, J. (2015). Informal networks and access to power to obtain housing in urban slums in Ghana. Africa Today 62(1), pp. 30-55.

PNDC. (1983). Decentralisation in Ghana. Accra: Information Services.

Republic of Ghana. (1992). Constitution of the Republic of Ghana, 1992. Tema, Accra: Ghana Publishing Corporation.

Republic of Ghana. (2012). White Paper on the report of the Constitution Review Commission of Inquiry. WP No.12012. Accra: Government of Ghana.

Republic of Ghana. (2014). Purpose and benefits of the Common Fund. In the Common Fund Newsletter: District Assembly Common Fund (DACF), Issue 1.

Resnick, D. (2014). Urban governance and service delivery in African cities: the role of politics and policies. Development Policy Review 32(S1): S3-S17.

Smoke, K. (2015). Managing Public sector decentralization in developing countries: Moving beyond conventional recipes. Public Administration and Development, 35, pp. 250-262.

Tsekpo, A. and Jebuni, C. E. (2008). Budget implementation and poverty reduction in Ghana. In The economy of Ghana: Analytical perspectives on stability, growth and poverty, by E. Aryeetey, R. Kanbur, (eds). UK: James Curry and Accra: Woeli Publishing Services.

World Bank. (2015). Rising through Cities in Ghana: Ghana urbanization review overview report. Washington DC.

Wunsch, J. S. and Oluwu, D. (1990). The failure of the centralised state: Institutions and self-governance in Africa (eds.). Boulder: Westview Press.

Yeebo, Z. (1985). Ghana: Defence committees and the class struggle. Review of African Political Economy 32, pp. 64-72. 